\title{
INDUSTRIAL HERITAGE OF NOVI SAD IN THE FUNCTION OF INDUSTRIAL TOURISM: THE CREATION OF NEW TOURIST PRODUCTS
}

DOI: http://dx.doi.org/10.18509/GBP.2015.63

UDC: 338.483.1]:725.1/66(497.113),2006/2014“6

\author{
Doc. Dr. Svetlana Vukosav \\ Doc. Dr. Vuk Garača \\ Ass. Prof. Dr. Nevena Ćurčić \\ Doc. Dr. Milan Bradić \\ University of Novi Sad, Faculty of Sciences, Department of geography, tourism and hotel \\ management, Novi Sad, Serbia
}

\begin{abstract}
The contemporary developments of tourism inthe last twenty years pointed tonew direction sand types of tourism, one of which is industrial tourism. Novi Sad as an industrial center of the Autonomous Provinceof Vojvodina has opportunities for development of tourism industry based on industrial heritage. The industrial heritage is put forward in order to create tourist flows and in many cases it acts as a catalyst for tourism policy and development. Novi Sad industry is mainly located in the industrial zones and has experienced in the seventies and eighties of the 20 th century in the great migration of the said zones, with the significant reconstruction of existing and construction of new capacity. The aim of this paper is to identify the industrial heritage resources for the development of industrial tourism in Novi Sad, and clearly determine their spatial distribution as well as connectivity options and the creation of new tourism products of Novi Sad.
\end{abstract}

Key words: industrial tourism, industrial heritage resources, reconstruction, new products, Novi Sad

\section{INTRODUCTION}

Industrialization represents such an important turning point of human history it has leant its name to an era. Over the past hundred and fifty years, due to changes in production practice civilization thoroughly changed. The identity of industrialization, its developmental characteristics and particular impact on human daily life are themes that are becoming increasingly attractive to a diverse and large crowd not only of researchers but also among the general public (Balažič, 2011).Considering this, at a time of stark change within the industrial era, tourism can play an important role in knowledge transfer, through the interpretation of industrial heritage, tradition sand culture in general. Industrial tourism is a type of tourism which involves visits to operational companies and industrial heritage; it offers visitors an experience with regard to products, production processes, applications, and historical backgrounds. More than 100 years ago public and private organisations already started to organise industrial tourism visits. Historic examples include visits to French wineries and chocolate factories, to Greek and Maltese lace-producers and to Dutch cheese producers (Frew, 2000). Industrial tourism offers opportunities for individual firms, but also for cities. Particularly for cities with a considerable industrial base, industrial tourism comprises interesting possibilities to 
strengthen the economic structure (direct and indirect employment) and to increase the supply of tourist products. For such cities industrial tourism is a potential growth sector that matches with their identity: the sector offers opportunities to strengthen their distinctiveness and image, notably by building on their existing assets. Many cities, however, have the assets to develop industrial tourism but fail to capitalise on them. In most cases industrial tourism is only restricted to low-profile company visits, withoutany clear vision of the municipality or firm on the strategic value of it, not to mention coordinated product development.This paper examines the resources of Novi Sad's industrial heritage, their locations and potential to be included in the current tourism demand. In the wake of socialism's downfall, and the economic and urban devastation of most cities in Serbia, Novi Sad, being its second largest city, has the potential to further its development of tourism by highlighting its preserved industrial resources and historical artefacts. In this manner, a new and attractive touristic product could be created, which could accelerate the city's development and the local economy. Industrial tourism is a form of innovative product which sets all local stakeholders in motion, and offers a complex experience to the tourists during their visit to Novi Sad.

\section{INDUSTRIAL HERITAGE AS A MEANS OF DEVELOPMENT OF INDUSTRIAL TOURISM}

Industrial heritage is a specific form of the human society's legacy, which emerged as a consequence of industrialisation, i.e. of the deindustrialisation of the society, certain industrial plants' facilities having been abandoned and most often left to decay. This was frequently the case with enormous complexes and industrial zones, and in that context industrial heritage is termed "the landscapes of nostalgia" (Garaca et al, 2014). When speaking of the legacy of industrial heritage, we primarily refer to the material remains of industry, and these are buildings and architecture, plants and factory works, machinery and equipment. Moreover, industrial heritage implies special industrial settlements, industrial landscape, products and processes as well as the industrial society's documents (Feifan, 2006). Industrial tourism is thus becoming an important socio-economic phenomenon (Mitchneck, 1998). The increase in popularity can be attributed to the growing de-industrialization of society, declining links with traditional processing and manufacturing systems and know-how, and the rise in computerized and automated production techniques (Beaudet \& Lundgren, 1996). Traditional industry, including numerous sites located underground (e.g., mines) or on the earth's surface (e.g., factories), provides tourists nostalgic and novel experiences.(Feifan, 2006). The idea is that industrial monuments may attract different types of tourists: older generations may search for nostalgia, whereas the younger ones may look for novelty. Industrial tourist activities are said to preserve a region's identity and to stimulate the formation of local service activities and employment. Cities that have an alternative blend of attractions on offer, like industrial tourism attractions, can be interesting for experienced tourists that have already seen most of the must see attractions. Especially foreign countries with a lot of mature and demanding tourists are interesting target markets for industrial tourism.Industrial tourism is not only a relevant market for second cities, but also an interesting addition for rather traditional tourist cities that are already successfully attracting tourists; visitors ask for a variation of the standard urban tourist programme, and industrial tourism could be an interesting tool to 'add some spice' to the existing tourist attractions, and hence create more appeal for second time visitors. 


\section{METHODOLOGY}

The content of this paper's research required that relevant methods be used. The deductive method has been applied, as well as the method of description in explaining the connections and relationships between the observed phenomena. Apart from these, other methods characteristic for research in tourism and humanities were used. Given that the fundamental methodological principle of humanities is based on dialectics, the dialectic, analytical-synthetic and verification methods were applied. Apart from that, the following methods were applied in this paper: statistical method, cartographic method and field research.

\section{INDUSTRIAL DEVELOPMENT OF NOVI SAD}

The industrial development of Novi Sad commenced in the mid- $18^{\text {th }}$ century, when, back in 1770 , the city got its first silk factory, which would remain the city's only industrial facility for many years to come. It was not before 1842 that the second industrial facility started operating, once again related to textile production, it being a steam powered weaving factory. During the revolution of 1848/49, the silk factory's building was damaged, and so in 1884, a new and significantly larger factory building was constructed and thus the silk factory became the city's industrial facility of great significance. In the following years, the industrial development was resumed when the slaughterhouse was constructed in 1885, followed by gasworks in 1888, and electric power works in 1909 (Petrović, 1987).

The development of industrial production was resumed at even greater a pace in the 20th century, so that in 1938, Novi Sad had over 80 companies employing over 5000 workers (Jovanović, 1994). In 1904, the renowned factory of Albus soap was opened, and in 1911, so was "Minakva" the factory for production and bottling of natural mineral water and non-alcoholic beverages. It should be emphasized that the period following the liberation from Austria-Hungary and the annexation of Vojvodina by the Kingdom of Serbia, i.e. the forming of the Kingdom of Yugoslavia, was the period when Novi Sad became an administrative centre, which was of particular significance for the development of the industry in this city. Namely, the "Danubius" pasta factory was constructed in 1919, the screw factory in 1921, the cable factory in 1922, cotton and silk weaving factory in 1925 (Tomić, 1990). Other factories include the Chemical industry of Novi Sad, as well as the "Ikarus" airplane and airplane parts factory in 1924, which produced the first airplane in Yugoslavia (Petrović, 1987). Today, the largest portion of industry is located in the North and South industrial zones, on both sides of the Danube-Tisa-Danube Canal. The entire complex has a well-developed infrastructure. It is situated outside the residential zone, equipped with devices which provide environmental protection, and includes spacious areas under vegetation.

\section{INDUSTRIAL HERITAGE OF NOVI SAD: DEVELOPMENT OF A NEW TOURISTIC PRODUCT}

Based on the above stated and numerous papers in this field, it can be concluded that, in its past, Novi Sad was a well-developed and relevant industrial city in which there remain numerous structures which testify of the diversified production works which were once situated there.

Several old industrial sites have been registered on the field. These are the areas at Liman 4 and Liman 2, those around the former railway station and the railroad, followed by those in Radnička Street, which implies the stretch between the Spens and the Quai of the Raid 
Victims, followed by the Podbara industrial area and the industrial zone which was situated between Kotorska and Šumadijska Street. The cited sites still house facilities belonging to former factories, which may therefore be considered industrial heritage, and may consequently be an interesting and attractive touristic resource. In that sense, the most important are the so-called Chinese Quarter, "Kineska četvrt", (the Petar Drapšin factory complex) and the Czech warehouse, which are situated at Liman. "Kineska četvrt" is an old industrial complex of the former "Petar Drapšin" factory, listed as the third category of Serbian industrial heritage, but does not enjoy legal protection. Its ambient value is enormous, and its structural capacities are inadequately used due to its long-term state of dereliction and lack of basic infrastructure. The potential which is offered by this space is extraordinary, and its revitalisation, alongside the introduction of new and contemporary content, would influence the development of tourism considerably, as well as the quality of the public space and life in the city. The Czech warehouse building was constructed in 1921 in the former industrial zone of the city. Since the documentation has not been recovered, it is assumed that it was used as a temporary storage facility for products, which were later transported to the North via the Danube. The spacious interior, featuring a large number of lean steel columns, distributed in two rows, eleven columns each, not covered by the web of wooden roofing beams, with a freight lift in the centre of the space, is being used today to house a part of the rich library fund of the Matica srpska (Internal materials of the Institute for Protection of Cultural Monuments, Novi Sad, 2015). The present industrial zones North and South, including the industrial zone West, were constructed following the year of 1950, when the Urban Master Plan of Novi Sad was reassessed. This resulted in the relocation of the industry to the surrounding area of the Savino Selo - Novi Sad canal, to the Futoški Road and to the North-East part of Petrovaradin. This was primarily caused by the increase in the number of citizens and the expansion of the city area, by the relocation of the railroad junction, by the Danube's course and by the Canal, as well as by the blowing direction of the prevalent winds (Jovanović, 1994).

The research on site showed that the majority of old factory facilities are in a very bad condition. It is often impossible to enter those facilities so as to evaluate their actual state. Nowadays, old factory workshops are quite often used as warehouses for the new factory's raw material base or for final products. There are cases of former factory space being rented to third parties for lesser scale craftwork and services.

Old factory buildings of the "Danubius" pasta factory in Radnička Street, and the silk factory on the corner of Kosovska and Almaška Streets, as well as the cotton weaver and the gauze and cotton pads factory "NIVA" on the corner of Šmadijska and Marka Miljanova Streets could be interesting for the development of industrial tourism in Novi Sad, as part of the industrial touristic product. Two mills have been registered as well, one of which is situated at the corner of Kisačka and Vuka Karadžića Streets, and the other one by the Temerinski Road, before the bridge to Klisa (Garaca et al, 2014). Moreover, there is the original factory workshop of the Albus soap factory, situated in Radnička Street, where, in its first years of production, soap was made with makeshift devices using technology which relied on the traditional household soap making experience (Tomić et al, 2005). In Petrovaradin, at the corner of Preradovićeva and Pavla Jurišića Šturma Streets, there is the Military-Technical Overhaul Institute. Old railway stations of Novi Sad and Petrovaradin may be identified as part of industrial heritage as well, the boiler-room at Jodna banja included. Special attention should be paid to the marshalling yard in Novi Sad. The facility was constructed in 1911, and is of semi- 
circular shape with 22 railroad tracks. The terminus was designed by the same team of architects who designed the Eiffel Tower of Paris. 20 meters of the diameter of the terminus are operational. In 2010, the City Assembly of Novi Sad enacted a detailed regulatory plan envisaging the terminus as a "place of gathering and a cultural centre". The terminus's operation may be displayed as performance for the tourists and visitors (Internal materials of the Institute for Protection of Cultural Monuments, Novi Sad, 2015).

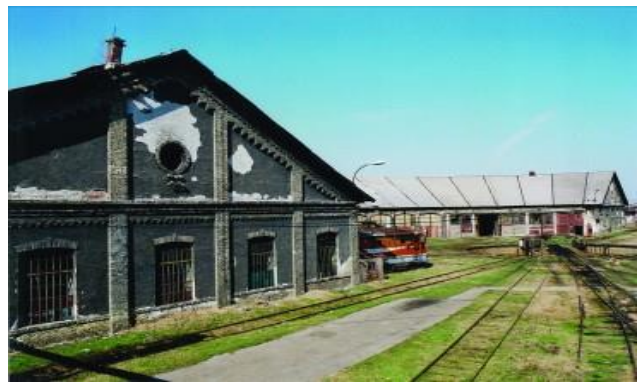

Picture 1. Marshalling yard

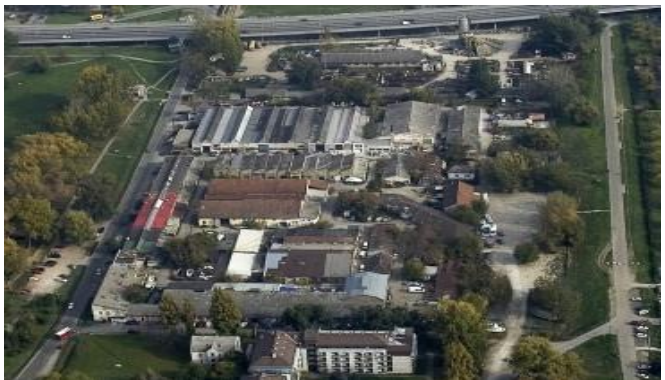

Picture 2. Old factory „Petar Drapšin”

Source:Institute for Protection of Cultural Monuments

Thus, Novi Sad and its surroundings feature several industrial heritage facilities which are already of interest or could be of interest to the tourists and may be generally distributed into the following groups:

1. Operational facilities receiving visitors

2. Operational facilities not receiving visitors

3. Relatively well-preserved non-operational facilities

4. Poorly preserved non-operational facilities

The old railway station buildings in Novi Sad and Petrovaradin housing the Post Office and the "Lovoturs" Company, and the former mill facility (now a grocery shop) in Kisačka Street could be listed under the first category. The second category of facilities could include: the Military-Technical Institute in Petrovaradin which is not open to the public and civilian visitors, the old marshalling yard, part of the Petar Drapšin factory (known as "Kineska četvrt"), as well as the Czech warehouse. The same category includes storage facilities of the former silk factory, which have been housing for a while now the scene and curtains workshop of the Serbian National Theatre, as well as the former factory facility at 20 Radnička Street, which houses the Open University and E-Learning High School. Standing out among the facilities which are in a good condition but are no longer operational are the original facilities of the "Albus" factory and of "Danubius" and "Niva" factories, and the large factory workshop of the Azotara nitrogen fertilizer plant. The last category of facilities could include the remnants of factory buildings of the silk factory at Podbara, which are in a state of dereliction, and the part of Petar Drapšin factory workshops (Picture 3). 


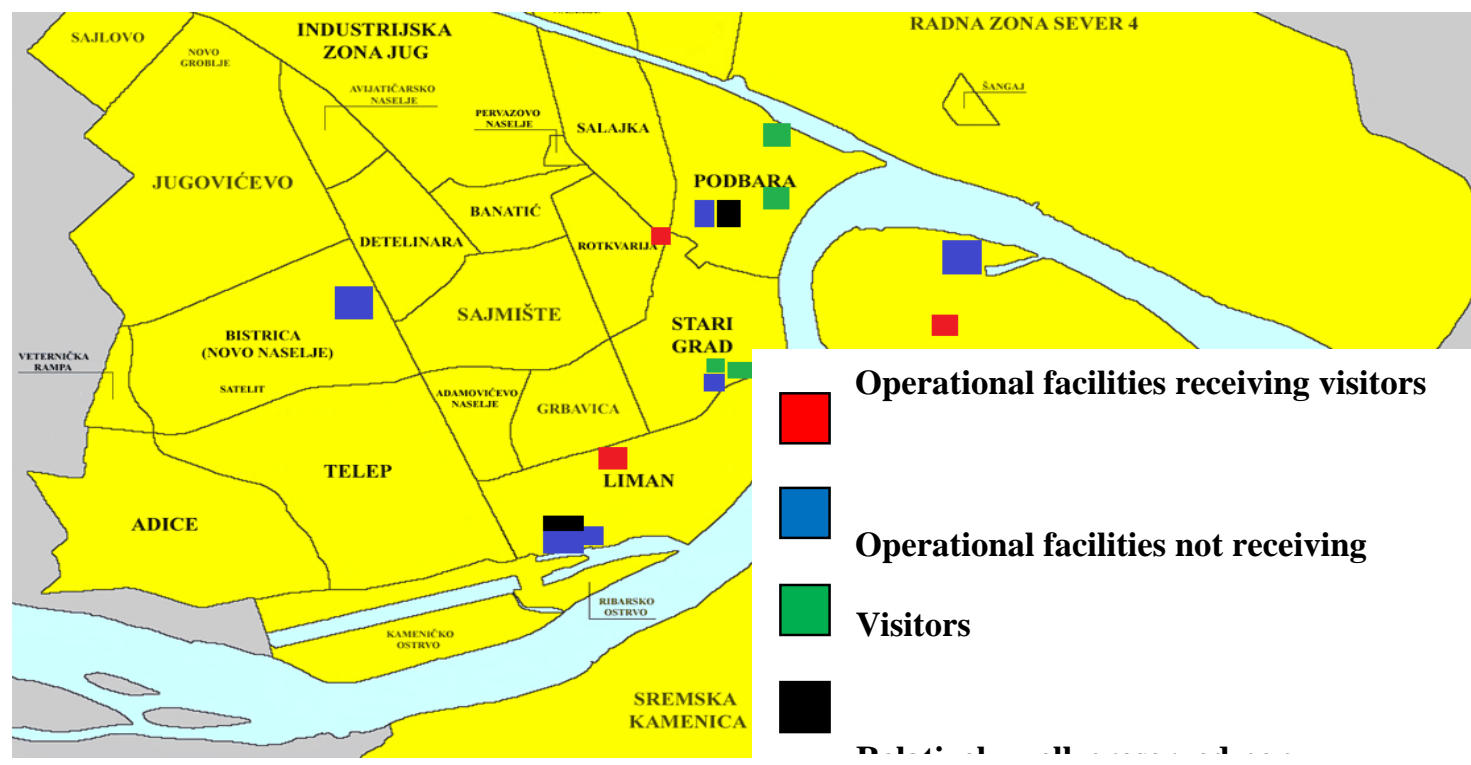

Picture 3. Spatial distribution of industrial heritage facilities in Novi Sad

\section{THE TURNOVER FROM TOURISM IN NOVI SAD AND THE POSSIBILITY OF ITS IMPROVEMENT THROUGH THE DEVELOPMENT OF INDUSTRIAL TOURISM}

As shown in Table 1, the turnover from tourism in Novi Sad has been in constant growth, with the exception of the 2009 and 2010 period, which was the height of the economic crisis. It is also evident that around two thirds of tourists are foreigners. This is above all caused by the visits made by the tourists to the internationally important manifestations, such as the Exit festival and the International Agricultural Fair. However, on European scale and in comparison with other countries and cities of Europe, the turnover from tourism is at a very low level. The basic issue which presents itself is how to fill the capacities during the entire year, because, with the exception of the periods during which the cited manifestations are held, the occupancy of accommodation in Novi Sad is relatively low. Moreover, the average tourist stay is low at 1.8-2.0 days. Therefore, the basic aim of the local Government's tourist policies should be directed at elongating the tourist stay, which would provide industrial tourism a chance to find its place in the city's tourist offer. The improvement of tourism, culture and the tradition of industrial production must be the aim of the future purpose and revitalization of industrial heritage facilities in Novi Sad. Renewing old production in small and exclusive series, where exclusivity and manual production and the adequate pricing would cover their shortcomings regarding productivity and thus yield an income, are the foundation of future actions regarding the revitalization of industrial heritage.

Table 1. The number of arrivals and overnight stays of tourists in Novi Sad (2006-2014)

\begin{tabular}{|llllllll|}
\hline Year & $\begin{array}{l}\text { Total } \\
\text { tourists }\end{array}$ & Domestic & Foreign & $\begin{array}{l}\text { Total } \\
\text { overnight } \\
\text { stays }\end{array}$ & Domestic & Foreign & $\begin{array}{l}\text { Avarage } \\
\text { stay }\end{array}$ \\
\hline 2006. & $\mathbf{7 4 5 6 8}$ & 39198 & 35370 & $\mathbf{1 4 6 9 5 1}$ & 72995 & 73956 & 2,0 \\
\hline 2007. & $\mathbf{9 7 0 0 8}$ & 50788 & 46220 & $\mathbf{1 8 3 4 6 1}$ & 81159 & 102302 & 1,9 \\
\hline 2008. & $\mathbf{1 0 4 0 2 7}$ & 57720 & 46307 & $\mathbf{1 9 1 8 6 3}$ & 93230 & 98633 & 1,8 \\
\hline 2009. & $\mathbf{8 6 9 2 0}$ & 40866 & 46054 & $\mathbf{1 6 7 2 5 3}$ & 67079 & 100174 & 1,9 \\
\hline 2010. & $\mathbf{9 2 6 2 0}$ & 41870 & 50750 & $\mathbf{1 6 8 3 4 7}$ & 68181 & 100166 & 1,8 \\
\hline 2011. & $\mathbf{1 0 6 4 3 3}$ & 43422 & 63011 & $\mathbf{2 1 3 5 4 9}$ & 70926 & 142623 & 2,0 \\
\hline
\end{tabular}




\begin{tabular}{|llllllll|}
\hline 2012. & $\mathbf{1 0 8 7 6 9}$ & 46361 & 62408 & $\mathbf{2 2 0 8 4 2}$ & 76211 & 144631 & 2,0 \\
\hline 2013. & $\mathbf{1 1 7 4 9 9}$ & 44307 & 73192 & $\mathbf{2 4 0 5 1 2}$ & 77534 & 162978 & 2,0 \\
\hline 2014. & $\mathbf{1 3 0 7 3 3}$ & 46132 & 84601 & $\mathbf{2 6 6 5 4 3}$ & 87544 & 178999 & 2,0 \\
\hline
\end{tabular}

Source: Statistical Office of the Republic of Serbia ,Statistical yearbooks (2007-2015)

The "Danubius" pasta factory possesses the original moulds and production lines for old types and shapes of pasta. Since the site and facility in which production commenced, back in 1919, is still existent, the old factory works which may still be operational should be reactivated and museum and touristic exhibitions should be launched, as well as the tasting of spaghetti, macaroni and noodles, which were made following the recipes of the old masters. Including tourists in the production process itself would be especially interesting. This kind of revitalization would be of great cultural and touristic significance, but of industrial significance as well, as it would demonstrate the long tradition of industrial production in our region. "Kineska četvrt" with the Czech warehouse in Novi Sad is one of the extraordinary examples of the potentially successful redefinition of the industrial space into the space intended for cultural purposes. The longterm interest of the cultural public of Novi Sad for "Kineska četvrt" and the fact that certain artists and organisations have, at their own initiative, already rented space at this location for their studios and workshops, speaks in favour of the fact that "Kineska četvrt" is currently perhaps the most adequate space for this kind of activity. The marshalling yard (its parts and its total space) - the boiler-room's central facility with the terminus are particularly interesting for being redefined into space for contemporary art production, due to its extraordinary cultural-historical importance and the fact that the terminus was designed by the Eiffel Tower team.

\section{CONCLUSION}

Industrial heritage may have its numerous and various functions and purposes, but its role in the general development of the community chiefly depends on the needs and priorities of its representatives and their decision on the purpose which would meet their needs in the best possible manner and secure common benefits. Novi Sad has a rich and diversified industrial heritage which may be used for multiple purposes, among which tourism definitely occupies an important place. There are parts of the town ("Kineska četvrt" e.g.) which currently represent places of collective memory in connection with industrial heritage and this is what could be the most powerful stimulus to the process of revitalisation of the industrial heritage. Experience and numerous examples of good practice from throughout Europe demonstrate that high quality revitalization projects are based on inter-sector partnerships and that their successful revitalisation requires the inclusion of and cooperation with the private and civilian sector, and that the support of state authorities is vital. Local authorities should have a crucial role in such processes as they are the ones who assess which projects make the best investments, what is of the greatest interest to the city. The first phase of the process of the revitalisation of monuments of industrial culture is to draw up a list of the existing facilities, followed by their valorisation which should be performed by state institutions in charge of cultural heritage preservation. The next phase is to revitalise industrial facilities by means of various relevant content which would contribute to the development of industrial tourism.

The authors would like to thank Secretariat for Science and Technological Development of Autonomous Province of Vojvodina for financially supporting this research (Project No.114-451-1485/2014-03). 


\section{REFERENCES}

[1] Balažić, G.Industrial heritage tourism in Slovenia: opportunities for sustainable tourism, Alvarez, Maria D. (ur.). Advances in hospitality and tourism marketing and management : conference proceedings, Istanbul, Turkey: Boğaziçi University,2011, pp. 519-524

[2] Beaudet, G., \& Lundgren, J.Industrial heritage. Teoros, 15(2), pp. 57-65, 1996.

[3] Feifan, P. Developing industrial heritage tourism: A case study of the proposed jeep museum in Toledo, Ohio, Tourism Management 27 (2006) pp.1321-1330, 2006.

[4] Frew, E.A.Industrial Tourism: a conceptual and empirical analysis. PhDThesis, Victoria University, 2000.

[5] Garaca, V., Trifkovic, A., Curcic, N., Vukosav, S. Aspects of Industrial Heritage Tourism: Case of Novi Sad. Revista de Cercetare si Interventie Sociala, 44, pp.181$198,2014$.

[6] Internal materials of the Institute for Protection of Cultural Monuments, Novi Sad, 2015.

[7] Jovanović, G. Industrija, u Novi Sad III, (urednik) Bogdanović, Ž., Univerzitet u Novom Sadu, Prirodno-matematički fakultet, Institut za geografiju, Novi Sad, 1994.

[8] Mitchneck, B. The heritage industry Russian style: The case of Yaroslavl. Urban Affairs Review, 34, pp. 28-52, 1998.

[9] Petrović, B. Novi Sad, Matica Srpska, Novi Sad, 1987.

[10] Statistical Office of the Republic of Serbia , Statistical yearbooks, (2007-2015).

[11] Tomić, P. Industrija, u Novosadske opštine II, (urednik) Davidović, R., Univerzitet u Novom Sadu, Prirodno-matematički fakultet, Institut za geografiju, Novi Sad, 1990.

[12] Tomić, P., Romelić, J., Jovanović, G. Industrija Bačke, PMF, Departman za geografiju, turizam i hotelijerstvo, Novi Sad, 2004 